\title{
頭䅡部領域におけるShe11を用いたチルト機構付き固定具の開発
}

\section{Immobilization Device with Shell for Head and Neck Region in Radiotherapy}

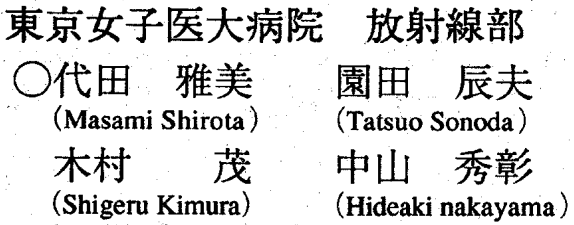

\author{
星野 君枝 \\ (Kimie Hoshino) \\ 稲葉 智宏 \\ (Tomohiro Inaba)
}

羽生 裕二
(Yuuji Hanyuu)
平林 久枝

(Hisae Hirabayashi)

【目的】当院ではShell使用時，市販のアクリルプレートを用いて照射を 行っているが,チルト機構がないため任意の照射体位がとれない。また照 射方向によっては表面線量の増加による皮庐炎，脱毛に注意が必要である. そこで吸収の少ないShell専用木製プレート（以下，木製プレート）を作 製し，当院で独自に開発，使用してきた頭頚部専用の木製チルト機構付き 固定具（以下, Head rest) と組み合わせ，有用性を検討した。

【使用機器及び構成】照射装置Linac NELAC1018 (NEC)X-ray 10MV : Shell頭頚部用（ORFIT）：固定用プレートB RF-102（ORFIT）木製プ レート（自作）：ヘッドネックサポートRF-103（ORFIT）：ランドファ ントム・タフウォータ (京都科学) : 線量計・シャロー形電離箱 $0.05 \mathrm{ccC}$ 134A（応用技研）・TLD素子LiF（natural） TYPE2600-58 (Victoreen) Fig. 1 にHead restと木製プレートの構成を示す.プ レートの材質は吸収の少ない木製で，現在使用して いるshellが使えるように設計した，Head restへの装 着は簡便な, はめ込み式とし，Shellを使用しない 時など症例に応じて使い分けが可能である。また Head restと木製プレートを装着しても角度調整には 影響がなく任意の照射体位が可能な機構とした。

【方法】(1)settingの再現性について照合写真より評 価した。 (2)Fig.3aに測定のシェーマを示す。表面位 置での入射線量についてシャロー形電離箱にて測定 した.Fig.4aにTLDによる実際の前後対向二門照射 を想定した，測定のシェーマを示す。アイソセンタ 一を $100 \%$ として後頭側の表面位置での入射線量を測 定した。素子は変動係数 $2 \%$ 以下 5 本 1 組を使用した

【結果及び考察】(1)Fig.2a,bにsettingの再現性のグ ラフを示す。縦軸は, 照合合計枚数, 横軸は, 前後方 向，頭足方向の動きの誤差を表す。 $\pm 2 \mathrm{~mm}$ 未満の 誤差が, 全症例数の $80 \%$ 以上であり，固定具とし て満足できる。(2)Fig.3bより，枕が厚くなるほど表

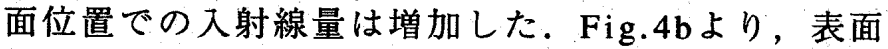
位置での入射線量はB,F枕で101.3〜105.4\%,スチロ ールでは83.5 87.1\%であり，スチロールなどの吸 收の少ない材質を使用する事が最適である。また Head restから皮屇まで距離があるため，木製，アク リルの違いよりも皮膚に密着する枕の材質に影響し た. Head restをビームが通過する照射法を選択して も吸収の補正の繁雑さがなく，スチロールが薄い場 合は, Head restからの, 表面位置での入射線量の増 加を防げるため木製が優れていた。

位置決め撮影から治療まで一貫して同じ固定具を使 用する事により，精度の高い再現性を保つことが出 来，またshel1の併用による照射中の動きの減少も期 待できる. (参考文献：日放技学誌 Vol.46 No.12, pp1947 1949,1990)

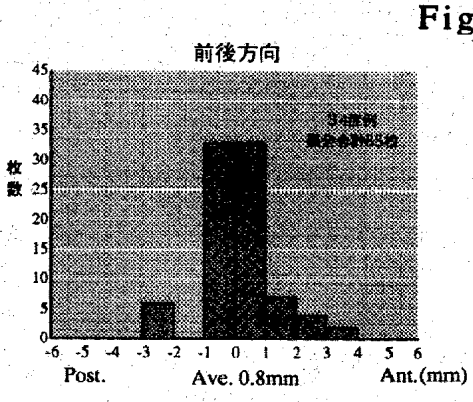

(a)

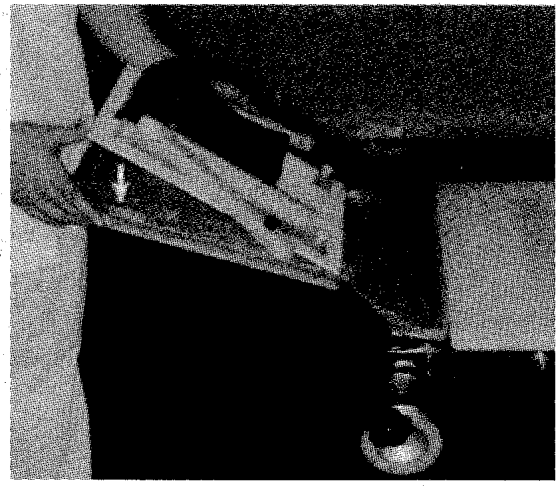

Fig.1 Shell専用木彆プレート

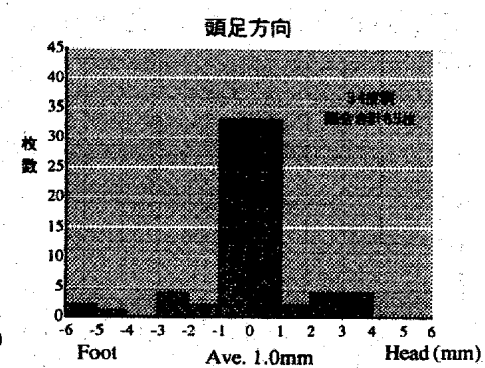

(b)

Fig.2 settingの再現性

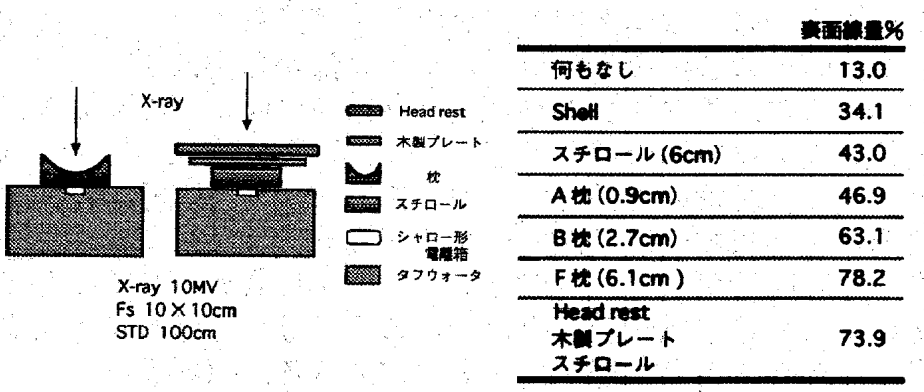

(a)

(b)

Fig.3 表面位置での入射線量

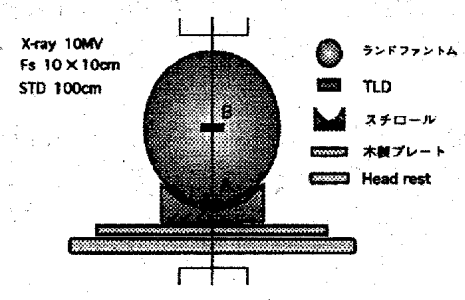

(a)

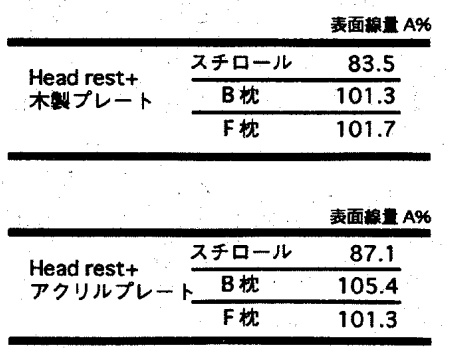

(b)

Fig.4 TLDによる表面位置での入射線量 